\author{
Review Article
}

\title{
APPRAISAL ON SPECIAL AYURVEDIC DIETARY FORMULAS FOR METABOLIC SYNDROME
}

\section{S Archana ${ }^{*}$, V C Indulekha ${ }^{2}$}

*1PG Scholar, ${ }^{2}$ Associate Professor, Department of Dravyagunavijnanam, Govt. Ayurveda College, Thiruvananthapuram, Kerala, India.

Article info

Article History:

Received: 11-10-2021

Revised: 28-10-2021

Accepted: 16-11-2021

\section{KEYWORDS:}

Santharpanajanya vikaras, Sthoulya,

Pathya-apathya,

Metabolic Syndrome.

\begin{abstract}
Metabolic syndrome and related complications are a major challenge for health providers of present era. Metabolic syndrome with key characters of abdominal obesity, insulin resistance, hypertension and dyslipidemia are the outcomes of faulty diet and habits. Since there are no such pharmacological agents which can reverse this condition more importance is being given to diet and lifestyle modifications. Traditional medicinal systems like Ayurveda gives equal importance for food and nutrition in both health and diseased conditions. Concept of Pathya -apathya for each and every disease is unique to Ayurveda where the macro and micronutrient principles were selected rationally for each disease conditions. These very principles can be adopted along with dietary supplements for curbing modern lifestyle disorders, more over there is mentioning of similar conditions in classics under a board term of Santharpanajanya Vikaras. Materials and methods: Thorough literary search done on various classical Ayurvedic texts for various diet and dietary preparations and online bases for their pharmacological properties from Ayurvedic and modern perspective and enlisted the dietary supplements. Results: Selected three major ingredients for the macro nutrient principles carbohydrate, protein and fat suggestive for MS from Sthoulya Prakarana and their properties are critically reviewed. Conclusion: There is enough scope of research in Ayurvedic dietary supplements for obesity and Metabolic Syndrome.
\end{abstract}

\section{INTRODUCTION}

Non-communicable diseases (NCD) have become the major cause of morbidity and mortality in developed as well as underdeveloped countries. Among NCD, metabolic syndrome had been the real blight globally. Metabolic syndrome, also known as syndrome $\mathrm{X}$, insulin resistance etc., is defined by WHO as a pathologic condition characterized by abdominal obesity, insulin resistance, hypertension, and hyperlipidemia. The incidence of metabolic syndrome often parallels the incidence of obesity and incidence of type 2 diabetes (one of the outcomes of MetS).[1] Ayurvedic classics while dealing with health and disease have a vivid concept on development on various disorders due to unhealthy dietary practices and lifestyles.

\begin{tabular}{|l|l|}
\hline \multicolumn{3}{|c|}{ Access this article online } \\
\hline Quick Response Code & \\
\hline
\end{tabular}

Many disorders under the caption of Santharpanajanya vyadhi resemble NCD s of present era. When etiology and pathogenesis of such disorders are analysed, show striking similarities with the present understanding of obesity, metabolic syndrome and associated complaints. Since etiology lies in Ahara and Vihara, they were given prime importance in curtailing Santharpanothaja vyadhis. Descriptions regarding a number of natural as well as processed foods which are advisable along with treatment in various conditions are seen in Caraka samhitha, Kasyapa Samhita Astanga Hrdaya etc. Search for dietary formulas with nutritional and pharmacological effects leads to global rise in functional and neutraceuticals market globally. Traditional medical systems like Ayurveda can significantly contribute in these fields both in research and product development.

\section{MATERIALS AND METHODS}

Thorough literary search done on various classical Ayurvedic texts for various diet and dietary preparations and online databases for their pharmacological properties, from Ayurvedic and 
modern perspective and enlisted the dietary supplements.

\section{Metabolic Syndrome in Ayurveda}

The metabolic syndrome (Syndrome $\mathrm{X}$ or Insulin Resistance syndrome) consists of a group of metabolic abnormalities that confer increased risk of Cardio Vascular Disease (CVD) and Diabetes Mellitus (DM). Central obesity, Hypertriglyceridemia, Decrease High Density Lipoprotein (HDL), Hyperglycaemia and Hypertension are the characteristic features. In short, metabolic syndrome and associated insulin resistance is the manifestation of physiologic malfunctioning of intracellular physiologic pathway. Insulin secretion and responses, the cellular redox and inflammatory states, and bodily insulin sensitivity got huge impacts through restricted food intake and quality selection of nutritional components[2]. Major etiological factors are westernized dietary patterns, characterized by a high consumption of meat or meat products, snacks, baked desserts and sugar-sweetened beverages, which provide high amounts of saturated fatty acids and simple carbohydrates as added sugars, along with sedentary habits have been associated with higher risk of MetS[3].

Concepts on obesity and lipid disorders have been vividly conceived in Ayurveda with context of Medoroga (Dyslipidemia), Prameha (Diabetes). Santarpajanya Vikaras is another area wherein Ayurvedic classics we could find vivid description on disease due to over nutrition and defective tissue metabolism. Sthoulya according to Acharya is in turn Nidana for many of the systemic disease. The prime aetiology of Sthoulya is Madhura, Snigdha, Guru, Sheetha Ahaara, Divaswapna and lack of physical exercises. Due to this Nidanas Medodhatu Vrddhi takes place leading to Sroto Avarodha by Medas causing Vata kopa due to obstruction which in turn vitiate Jadaragni..[4] Vata causes Vishamagni resulting in Teekshanagni in Koshta and Mandagni in case of Dhatu Agni. Teekshnagni in Koshta results in increase in food consumption and Sthoulya (Atitrishna, Atikshudha, Swedadhikya, Alasya) occurs.

\section{Special Diet Mentioned in Classics}

Pathya ahaara mentioned in the treatment of obesity is of view of providing nutritional benefit as well as plays an important role in Samprathi Vighatana or mitigating pathogenesis. Principle applied here is Guru cha Apatarpanam. Means heavy and non-satiating (nourishing). From Dosha point of view diet and drinks alleviating Vata-Sleshma and Dhatu level it should reduce Medas and Mamsa should be used[5]. Food as per western medicine comprise of macronutrients and micronutrients. While considering management of obesity selection of the components can also be made. According to Carakacharya as a wholesome diet use of cereals and millets other than conventionally used can be taken depending on the availability. For example, Prasatika, Priyangu, Shyamaka, Yavaka, Yavajurna, Kodrava etc., for carbohydrate base and for protein Mudga, Kulattha, Cakramudga, Makushta. Here more emphasis given for millets rather than cereals was seen. It should be taken properly in divided doses and appropriate form. Regular dietary formula depending on availability and use Yava, Mudga, and also meat of animals belonging to Jangala Desa can be chosen.[6] Table: 1 shows their dietary preparations as described wholesome for Santharpanajanya Vikaras in various Ayurvedic texts.

Table:1 Preparations of Yava, Mudga and Mamsa described wholesome in Santharpanajanya Vikaras

\begin{tabular}{|c|c|c|}
\hline Yava & Mudga & Mamsa \\
\hline $\begin{array}{l}\text { Yava Amalaka Choorna (powder) } \\
\text { Yava Mantha (Churned drinks) } \\
\text { Yavachoorna Leha (licking food made } \\
\text { out of powder of Yava) } \\
\text { Yava Saaktu (flour of Yava) } \\
\text { Yava oudanam (boiled Yava) } \\
\text { Yava vatyaa (gruel prepared of Yava) } \\
\text { Apupa (bread recipe of Yava) } \\
\text { Triphala processed Yava } \\
\text { Guda mukta Yava (semi processed Yava } \\
\text { after feeding to domestic animals) } \\
\text { Yavarotika (roti prepared of barley) }\end{array}$ & $\begin{array}{l}\text { Yusha (soup) } \\
\text { Mudga yusha prepared alone } \\
\text { or mixed with bitter } \\
\text { vegetables like Karavela, } \\
\text { Patola etc } \\
\text { Krsara/Kichadi } \\
\text { Mudga vataka }\end{array}$ & $\begin{array}{l}\text { Mamsa rasa of Viskira, } \\
\text { Praduta and animals of } \\
\text { Jangala Desa Soolya mamsa } \\
\text { (roasted on rod) } \\
\text { Parisuska mamsa (dried } \\
\text { meat) }\end{array}$ \\
\hline
\end{tabular}

Analyzing food preparations as Pathyaahara for Sthoulya showed special emphasis was given for Yava, Mudga and Jangala Mamsa. Yava is botanically identified as Hordeum Vulgare L., Mudga Vigna radiate (L.) and Mamsa (white meat). Properties of these as per various Ayurvedic classics and modern pharmacology as given in table: 2 
Int. J. Ayur. Pharma Research, 2021;9(11):66-70

Table 2: Ingredients with Properties - Ayurvedic and Modern

\begin{tabular}{|c|c|c|c|}
\hline \multicolumn{2}{|c|}{ Ingredient } & Properties & Pharmacological actions \\
\hline \multicolumn{2}{|l|}{ Yava } & $\begin{array}{l}\text { Rukshsa, Sheeta, Aguru (not heavy), } \\
\text { Kashaya, Balya, Sleshmavikaranut } \\
\text { Kashaya Madhuram, Sheetam (cold) } \\
\text { Katuvipakam } \\
\text { Prabadha mutram (anti-diuretic) Agni Meda } \\
\text { Krt (promotes digestive power, intellect) } \\
\text { Sthula Vilekhana (reduce body weight in } \\
\text { obese) Medo Maruta haranam (eliminates } \\
\text { fat, Vata, thirst) Prasadana of Rakta and } \\
\text { Pitta. } \\
\text { Kapha pitta samana (su.su) }\end{array}$ & $\begin{array}{l}\text { Antioxidant } \\
\text { Hypocholesteremic } \\
\text { Diuretic } \\
\text { Hypoglycemic } \\
\text { Anti-inflammatory } \\
\text { Hepatoprotective }\end{array}$ \\
\hline \multicolumn{2}{|l|}{ Mudga } & $\begin{array}{l}\text { Kashaya Madhuram, Ruksham Sheetam, } \\
\text { Katu vipakam, Laghu } \\
\text { Vishadam, Kapha pitta haram } \\
\text { Supothama }\end{array}$ & $\begin{array}{l}\text { Diuretic, antioxidant, } \\
\text { antidiabetic, antihypertensive, } \\
\text { anti-inflammatory, } \\
\text { hypolipaedemic }\end{array}$ \\
\hline \multirow[t]{3}{*}{ Mamsam } & $\begin{array}{l}\text { Viskeeram } \\
\text { (Gallinaceous birds) }\end{array}$ & \multirow[t]{3}{*}{$\begin{array}{l}\text { Laghu, Sheetam, Madhuram } \\
\text { Kashayam, Tridosha haram }\end{array}$} & \multirow{3}{*}{$\begin{array}{l}\text { Mono unsaturated fatty acids } \\
\text { Omega }-6 \text { or } n-6 \text { linoleic acid } \\
\text { Arachidonic acid. }\end{array}$} \\
\hline & Praduda (peckers) & & \\
\hline & Jangalam & & \\
\hline
\end{tabular}

Yava is having property of cleansing of channels and thereby derangement of Vata is corrected. Yava reduce Medas and controls urine output, benign with all the Dhatus (neither increase nor decrease) and particularly prescribed in Prameha. ${ }^{[7]}$

Invitro studies using Yava mantha (churned drink) in diabetes shows potential of being a natural hyperglycaemic inhibitor by delaying the absorption of dietary carbohydrates in the intestine, probable mechanism through inhibition of alpha-amylase and alpha-glucosidase.[8] Study on effect of hydroalcoholic extract of barley on streptozotocin induced diabetes in rats showed good hyperglycaemic control on long term consumption. ${ }^{[9]}$ Yava identified as Hordeum vulgare is rich in phytochemicals such as beta-glucan, phenolic acids, flavonoids, lignans, tocols, phytosterols, folates etc. Phytochemicals especially tocols, folates, phytosterols prevent cardiovascular events. Betaglucan water soluble fibre prevalent in the Yava shown to have property of altering cholesterol mechanism [10]. The high antioxidative activity due to phytochemicals present in barley makes it a useful natural means for preventing development of obesity and diabetes. Probably through curbing of systemic, low-grade inflammation, especially in adipose tissue, which in turn is a trademark of obesity and diabetes.[11] High dietary fibre intake especially soluble type have the advantages of improved glycemic control, decreased hyperinsulinemia and plasma lipid concentrations in patients with type 2 diabetes [12]. Clinical trials with barley beta glucan as supplement to meals rather than to beverages improves post glycaemic response in healthy volunteers [13]. More over Yava or barley is having more hypocholestraemic activity in comparison to wheat.[14]

Caraka Acharya mentioned Mudga as best example for Svabhava laghu- naturally lighter for digestion makes an ideal choice for wholesome diet. Soup of green gram plain or processedmitigates Kapha, kindles digestion, good for heart, ideally suited to persons who have been administered purificatory therapies (emesis, purgation, etc.) and the wounded. Yusha is appetizer, aphrodisiac, cures anorexia, good for throat, strength promoter and enhances skin complexion. ${ }^{[15]}$

As evidenced from certain randomized control trials Watanabe Y, Suzuki D, Kuribayashi N, et al inDiabetes Mellitus patients, decreased serum insulin, body fat mass and increased HDL level were seen in protein and protein enriched diet when compared to fat rich diet [16] Mudga is best among pulses which can be utilized in the form of soup. Pulses have Kaphamedohara property and are Pathya in cardiovascular disease and obesity which are proven through modern researches. Consumption of legumes also has been associated with reduced risk of coronary heart disease.[17] Mudga can be considered wholesome diet in obesity and MS as it is rich in fibre and protein. Invivo studies using high fat diet supplemented with decorticated Mung bean flour in mice effectively alleviate HFD induced metabolic disorders accompanied by reduction in hepatic steatosis ${ }^{[18]}$ It produces longer satiety times due to the double increase of the satiety hormone cholecystokinin. Studies on Golden Hamster model shows significant reduction in plasma TC, TG, non-HDL-C, non-HDLC/HDL-C and TC/HDL-C levels in hamsters fed a high 
cholesterol diet and this activity was associated with inhibition in cholesterol absorption.[19] Green gram based high fat diet when fed to Sprague Dawley rats for 12 weeks significantly reduced fat accumulation, serum cholesterol, triglycerides, serum aspartate aminotransferase, and alanine aminotransferase and also prevented adipose tissue hypertrophy and hepatic steatosis.[20] It maintains the level of magnesium in the blood, which eases blood vessels and lowers hypertension. Green gram possesses property of preventing oxidation of LDL thereby keeping the arteries clear and improving blood circulation. This reduces inflammation and reverses damage to the blood vessels. The risk of heart attack and stroke is also reduced by preventing deposition of plaque.[21]

Meat is an important structure in global dietary structure rich in protein, fat, iron Zinc and Vitamin B12. Even though with above properties red meat especially processed is having a higher risk of causing metabolic syndrome while white meat (poultry) is having low risk of MS. However, studies show consumption of processed meat accelerates development of obesity and related complications [22]. Compared to red meat, white meat contains a high proportion of polyunsaturated fatty acids and a low proportion of saturated fatty acids. These differences in fat content might be the reason for the opposite effect of red and white meat on the risk of metabolic syndrome. ${ }^{[23]}$ Total fat and saturated fat concentrations are distinctly higher in many types of processed meat, with extreme values of up to $90 \mathrm{~g} / 100 \mathrm{~g}$ total fat and $25 \mathrm{~g} / 100 \mathrm{~g}$ saturated fat in fatty bacon.

While mentioning Mamasa as Pathya Ahara Acarya gives much importance in the processing of meat before consumption. Meat inserted to a sharp iron rod and roasted over red hot coal without smoke is called Sulya Mamsa or grilled meat. Sulyamamsa considered as best variety of meat dishes which will be Laghu and Pathya (in fact best among Pathya) in nature.[24]

\section{DISCUSSION}

A human dietary pattern consists of macronutrient principles of carbohydrate, proteins and fat, micronutrients vitamins and principles. Specific dietary modifications are an integral part of management of obesity and other related metabolic syndrome. This includes improving the quality of food and also changing the macronutrient composition. Health professionals all over the world are in search of a standard dietary pattern in this lifestyle disorders. Selecting Yava, Mudga and Jangalamamsa as major ingredient in regular diet providing macronutrients suggestive for MS from Sthoulya Prakarana and properties both Ayurvedic and pharmacological were critically reviewed. Incorporating fibre rich, low calorie, low fat and anti-oxidant rich food is the primary requirement in dietary management of MS. $\beta$ glucan fiber and starch composition ratio of amylose to amylopectin in Yava or barley is found to be responsible decrease in glucose level. Lekhana guna of Yava makes Medo dhatu Vilayana, which helps in reducing Medodusti, so it is beneficial in obesity. Yava contain more soluble dietary fibre which form bulk and prevent excessive absorption of glucose. Yava can be used therapeutically by enriching its potential by utilizing various processing techniques and also incorporating various hypoglycaemic drugs mentioned in classics.

Kashaya-Ruksha, Laghu guna and Katuvipaka accounts for Kapha Medoharatwa mudga Yoosha. Antioxidant property of green gram is due to presence of vitexin and isovitexin. These are with potent reactive oxygen and nitrogen scavenging activity along with LDL inhibition. Vitexin significantly protective effect in peripheral blood vessels, regulates flora of enterobacteria. It is with property of normalizing plasma lipid profile, insulin sensitivity. Both Yava and Mudga consist of large amount of dietary fibres along with other nutritional factors like vitamins, minerals. The anti-nutritional factors present in the green gram too posses certain health benefits as evident from meta analysis of both clinical and preclinical studies conducted globally.

Meat and meat products remaining as an integral part of global dietary pattern replacement of read and processed red meat with white meat will be a healthy alternative along with a check in the amount of consumption. Since white meat especially poultry is having more nutritional benefits with the presence of essential fatty acid $s$ and more protein compared to red meat. Processing methods as mentioned in Ayurveda classics can be adopted and products obtained can be analysed in terms of nutritional values and compared with currently available processed food. This can be utilized in dietary management of obesity related disorders.

\section{CONCLUSION}

Lifestyle disorders are increasing at an alarming rate among people not only in developed countries but also in developing nations too. Need of intervention especially at the dietary level is necessary to avoid a huge economic burden in health sector in nearby future. Ayurveda emphasize importance of food more along with medicine in curbing Santharpanajanya vikaras which can be attributed to present day life style disorders. Diet, dietary patterns mentioned as Pathya in Santharpanajanya vikaras should be analyzed in light of metabolic syndrome like disorders using current research methodology and incorporating in dietary management will yield promising results. 


\section{REFERENCES}

1. Saklayen MG. The global epidemic of the metabolic syndrome. Current hypertension reports. 2018 Feb; 20(2): 1-8.

2. $\mathrm{Xu} \mathrm{H}, \mathrm{Li} \mathrm{X}$, Adams H, Kubena K, Guo S. Etiology of metabolic syndrome and dietary intervention. International journal of molecular sciences. 2019 Jan; 20(1): 128.

3. Martinez-Gonzalez MA, Martin-Calvo N. The major European dietary patterns and metabolic syndrome. Reviews in Endocrine and Metabolic Disorders. 2013 Sep; 14(3): 265-71.

4. Sowmya MN, Nanjammanni N. Dietary intervention in Sthoulya (obesity). Journal of Ayurveda and Integrated Medical Sciences. 2021 Sep 15;6(4):252-4.

5. Dash B. Caraka Samhita, Chaukhamba Sanskrit Series Office Varanasi, Reprint. 2011. Sutra sthana-27/19.

6. Dash B, Sharma RK. Caraka Samhita, Chikitsa sthan. Chowkhamba Sanskrit series office. Varanasi. 1995. Tripathi B. Ashtanga Hridaya of Vagbhata. Sutrasthana 3rd. 2009: 19-20.

7. Shastri B. Yogaratnakara. Chaukhambha Sanskrit Sansthan, Varanasi. 2005; P.768.

8. Harshitha K. Anti-Diabetic Potential of Yava ManthaAn In Vitro Study. Journal of Ayurveda and Holistic Medicine (JAHM). 2018;6(3):18-2.

9. M Minaiyan, A Ghannadi, A Movahedian, I HakimElahi. Effect of Hordeum vulgare L. (Barley) on blood glucose levels of normal and STZ-induced diabetic rats. Res Pharm Sci. May-Jun 2014; 9(3): 173-8.

10. Shinnick FL, Mathews R, Ink S. Serum cholesterol reduction by oats and other fiber sources. Cereal foods world (USA). 1991.

11. Dr.D.V.Kulkarni, Dr.Ruchita R.Kudale, and Dr.Renuka S.Pawar, Role of Yava (Hordeum vulgare Linn.) as a Swastyahita Aahara Dravya International Research Journal of Pharmacy and Medical Sciences (IRJPMS), Volume 2, Issue 1, 2018, pp. 32-35.

12. Chandalia M, Garg A, Lutjohann D, Von Bergmann K, Grundy SM, Brinkley LJ. Beneficial effects of high dietary fiber intake in patients with type 2 diabetes mellitus. New England Journal of Medicine. 2000 May 11; 342(19): 1392-8.

13. Poppitt SD, van Drunen JD, McGill AT, Mulvey TB, Leahy FE. Supplementation of a high-carbohydrate breakfast with barley beta-glucan improves postprandial glycaemic response for meals but not beverages. Asia Pac J Clin Nutr. 2007; 16(1): 16-24.
14. McIntosh GH, Whyte J, McArthur R, Nestel PJ. Barley and wheat foods: influence on plasma cholesterol concentrations in hypercholesterolemic men. Am J Clin Nutr. 1991; 53(5): 1205-1209.

15. Sharma MB, Zala U, Patel K, Bhatt C. Pharmaceutical standardization and a brief review of nutritional values of three Ayurveda recipes sequentially used after Panchakarma. J Indian Sys Medicine 2020; 8: 287-92.

16. Watanabe Y, Suzuki D, Kuribayashi N, et al. A randomized controlled trial of two diets enriched with protein or fat in patients with type 2 diabetes treated with dapagliflozin.Sci Rep.2021;11(1): 11350.

17. Bagde A, Ramteke A, Nimbalkar M, Tirpude S. Nitya Sevaniya Aahara (Wholesome Daily Food) In Ayurveda- Review Article. World Journal of Pharmacy and Pharmaceutical Sciences. Volume 8, Issue 3,362372.

18. Hou D, Zhao Q, Yousaf L, Xue Y, Shen Q. Whole mung bean (Vigna radiata L.) supplementation prevents high-fat diet-induced obesity and disorders in a lipid profile and modulates gut microbiota in mice. Eur J Nutr. 2020; 59(8): 3617-3634. doi:10.1007/s00394020-02196-2.

19. Yao Y, Zhu Y, Ren G. Mung bean protein increases plasma cholesterol by up-regulation of hepatic hmgcoa reductase, and cyp7a1 in mrna levels. Journal of Food and Nutrition Research. 2014 Oct 14;2(11): 770-5.

20. Hou D, Zhao Q, Yousaf L, Khan J, Xue Y, Shen Q. Consumption of mung bean (Vigna radiata L.) attenuates obesity, ameliorates lipid metabolic disorders, and modifies the gut microbiota composition in mice fed a high-fat diet. Journal of Functional Foods. 2020 Jan 1; 64: 103687.

21. https://www.lybrate.com/topic/mung-beans-greengram-benefits\#

22. Guo H, Ding J, Liang J, Zhang Y. Association of Red Meat and Poultry Consumption with the Risk of Metabolic Syndrome: A Meta-Analysis of Prospective Cohort Studies. Frontiers in Nutrition. 2021: 410.

23. Kim Y, Je Y. Meat consumption and risk of metabolic syndrome: Results from the Korean population and a meta-analysis of observational studies. Nutrients. 2018 Apr; $10(4): 390$.

24. Shastry JL. Illustrated Madanapala nighantu. Varanasi, India: Chaukhambha Ayurveda Pratisthana. 2010. P.780.

*Address for correspondence
Dr. C S Archana
PG Scholar,
Department of Dravyaguna,
vijnanam, Govt. Ayurveda College,
Thiruvananthapuram, Kerala, India.
Email: archanacprabha@gmail.com
Ph: 9633096768

Disclaimer: IJAPR is solely owned by Mahadev Publications - dedicated to publish quality research, while every effort has been taken to verify the accuracy of the content published in our Journal. IJAPR cannot accept any responsibility or liability for the articles content which are published. The views expressed in articles by our contributing authors are not necessarily those of IJAPR editor or editorial board members. 